\title{
HUBUNGAN ANTARA SELF EFFICACY (KEYAKINAN KEMAMPUAN DIRI) DENGAN KELULUSAN RETAKER UKMPPD DI UNIVERSITAS MALAHAYATI
}

\author{
Supriyati ${ }^{1}$, Octa Reni Setiawati ${ }^{2}$, Vira Sandayanti ${ }^{3}$ \\ 1,2,3Prodi Psikologi Fakultas Kedokteran, Universitas Malahayati. Email: supriyati@malahayati.ac.id
}

\section{ABSTRACT: SELF-EFFICACY IN A PROFESSIONAL COMPETENCY TEST AMONG MEDICAL STUDENTS}

Background: To have competence as a doctor, the medical student have to pass examination a Professional Competency Test to obtain doctoral diplomas from educational institutions and competency certificates from institutions that authorized. The data obtained based on passing student examination a Professional Competency Test at Malahayati University showed an average number of $48.75 \%$. Many factors can influence the success of student learning in students, one of which is the efficacy of self efficacy. Individuals who have high self efficacy will direct someone to better achievement in various fields.

Purpose: This study aims to examine the relationship between self efficacy with passing number student examination a Professional Competency Test at Malahayati University.

Methods: The variable in this study is self-efficacy as an independent variable and passing number student examination a Professional Competency Test as a dependent variable. The research sample in this study were medical profession students who passed examination a Professional Competency Tes. The method of collecting data was using the scale self efficacy and a Professional Competency Tes document. Data analysis method uses product moment.

Results: The value are $r 0.673$ with $p=0,000$ where $(p<0.01)$ means that there is a very significant positive relationship between self efficacy and passed student examination a Professional Competency Test at Malahayati University, Bandar Lampung.

\section{Keywords: Self Efficacy, student, examination, Professional Competency Test}

Pendahuluan: Mahasiswa dikatakan memiliki kompetensi sebagai seorang dokter jika telah menuntaskan Uji Kompetensi Mahasiswa Program Profesi Dokter (UKMPPD) untuk memperoleh ijazah dokter dari institusi pendidikan dan sertifikat kompetensi dari institusi yang berwenang. Data yang diperoleh berdasarkan tingkat ketidaklulusan UKMPPD mahasiswa program profesi dokter Universitas Malahayati menunjukkan angka rata-rata sebesar $48,75 \%$. Banyak faktor yang dapat mempengaruhi keberhasilan belajar mahasiswa pada mahasiswa, salah satunya adalah self efficacy. Self efficacy. Individu yang memiliki self efficacy yang tinggi akan mengarahkan seseorang pada prestasi yang lebih baik dalam berbagai bidang.

Tujuan: Penelitian ini bertujuan untuk meneliti hubungan antara self efficacy (keyakinan akan kemampuan diri) dengan kelulusan retaker UKMPPD di Universitas Malahayati.

Metode: Variabel dalam penelitian ini adalah self efficacy sebagai variabel bebas dan kelulusan retaker UKMPPD. Sampel penelitian dalam penelitian ini adalah mahasiswa profesi dokter yang menjadi retaker pertama pada ujian UKMPPD.Metode Pengumpulan data dengan menggunakan skala self efficacy dan dokumen kelulusan UKMPPD. Metode analisis data menggunakan product moment.

Hasil: Nilai $r$ sebesar 0,673 dengan $P=0,000$ dimana $(p<0,01)$ artinya ada hubungan positif yang sangat signifikan antara self efficacy dengan kelulusan retaker UKMPPD Universitas Malahayati Bandar Lampung.

\section{Kata kunci: Self Efficacy, Kelulusan, Retaker, UKMPPD}

\section{PENDAHULUAN}

Profesi dokter masih dipandang sebagai profesi yang eksklusif dan banyak lulusan Sekolah Menengah Atas memilih jurusan kedokteran sebagai pilihan favorit untuk karirnya yang ingin merubah nasib dengan menjadi seorang dokter. Namun pada praktiknya untuk dapat lolos menjadi mahasiswa kedokteran tidaklah mudah, harus berjuang lebih keras dibandingkan profesi yang lain. Setelah diterima menjadi mahasiswa kedokteran mereka dituntut lebih maksimal dan memiliki keyakinan yang kuat untuk berhasil menyelesaikan kuliah dengan baik.

Mahasiswa dikatakan memiliki kompetensi sebagai seorang dokter jika telah menuntaskan Uji Kompetensi Mahasiswa Program Profesi Dokter (UKMPPD) untuk memperoleh ijazah dokter dari institusi pendidikan dan sertifikat kompetensi dari 
institusi yang berwenang (Konsil Kedokteran Indonesia, 2006).

Ujian mengacu pada Standar Kompetensi Dokter Indonesia (SKDI) dan Standar Pendidikan Profesi Dokter (SPPD) ini hadir dalam bentuk teori dan praktik.Ujian praktik diujikan menggunakan Objective Structured Clinical Examination (OSCE) yakni suatu metode untuk menguji kompetensi klinik secara obyektif dan terstruktur dalam bentuk putaran station dengan waktu tertentu. Objektif karena semua mahasiswa diuji dengan ujian yang sama dan terstruktur karena yang diuji adalah keterampilan klinik tertentu dengan menggunakan lembar penilaian tertentu (Konsil Kedokteran Indonesia, 2006). Gambaran di atas mahasiswa yang mengikuti UKMPPD diharapkan dapat mengikuti ujian dengan baik sehingga memperoleh hasil yang diharapkan yaitu dinyatakan lulus UKMPPD, sebagai dasar calon dokter dinyatakan kompeten menjalankan profesi sebagai dokter. Namun pada kenyataannya masih banyak mahasiswa fakultas kedokteran yang mengikuti UKMPPD hanya beberapa yang dapat lulus UKMPPD first taker (UKMPPD yang pertama).

Data menunjukkan dibeberapa perguruan tinggi yang melaksanakan UKMPPD khususnya di Universitas Malahayati data tahun 2013 peserta yang tidak lulus UKMPPD dalam prosentase sebesar $44,4 \%$, tahun 2014 sebesar 53,5\%, tahun 2015 sebesar 53,9\%, dan 2016 sebesar 43,2\%. Data yang diperoleh berdasarkan tingkat kelulusan UKMPPD mahasiswa program profesi dokter Universitas Malahayati menunjukkan angka ratarata sebesar $48,75 \%$, artinya tingkat kelulusan peserta ujian UKMPPD masih sedikit diatas angka $50 \%$. Tingkat kelulusan yang masih belum optimal dikarenakan adanya tuntutan akademik yang besar dalam menyelesaikan program profesi dokter (Santoso, Lusida, Farida \& Husaeni, 2017).

Banyak faktor yang dapat mempengaruhi keberhasilan belajar mahasiswa pada mahasiswa, diantaranya adalah lamanya waktu belajar, lingkungan tempat tinggal , Self efficacy, banyaknya tanggungan keluarga, Intelligent Quotient (IQ), kondisi tempat kuliah, dan sarana belajar yang digunakan (Warsito, 2012)

Penelitian ini untuk meneliti hubungan antara self efficacy (keyakinan akan kemampuan diri) dengan kelulusan retaker UKMPPD di Universitas Malahayati. Self efficacy diartikan sebagai keyakinan seseorang mengenai kemampuan dirinya dalam melakukan tugas atau tindakan yang diperlukan untuk mencapai hasil tertentu.Individu yang memiliki self efficacy yang tinggi akan mengarahkan seseorang pada prestasi yang lebih baik dalam berbagai bidang karena self efficacy akan mengaktifkan perubahan psikologi yang mengurangi rasa sakit dan lebih dapat mentolerir stress. Self-efficacy sebagai kepercayaan akan kemampuan seseorang dalam skenario tertentu seperti percaya pada kemampuan mereka untuk melakukan suatu tugas atau belajar diberi informasi. Self eficacy adalah perasaan berperan seorang mahasiswa yang membangun kesadaran tentang keberadaan dirinya (Pujiastuti, 2012; Kusumadewi, 2014; Dwitantyanow, Hidayati, \& Sawitri, 2010; Widyastuti, 2013; Astarini, 2015; Hermawan, 2014). Self-efficacy dan minat telah sering diidentifikasi sebagai faktor motivasional penting yang mempengaruhi pembelajaran dan kinerja. Akhir-akhir ini konsep Self efficacy memainkan peranan penting dalam menghadapi masalah motivasi dan kinerja suatu tugas (Niemvirta \& Tapola, 2007; Wijaya, 2008; Subaidi, 2016). Uji Kompetensi Mahasiswa Program Profesi Dokter adalah suatu proses untuk mengukur pengetahuan, keterampilan dan sikap tenaga kesehatan sesuai dengan standar profesi. Pelaksanaan uji kompetensi bertujuan untuk meningkatkan mutu tenaga kesehatan dibidang kognitif, afektif dan psikomotorik dengan harapan dapat menghasilkan lulusan yang berkualitas (Sutomo, Hartanto \& Dwijayanti, 2017).

Uji kompetensi sebagai sistem penjaminan mutu lulusan dokter telah diatur secara tersurat dalam Undang-Undang No 29 Tahun 2004 tentang Praktik Kedokteran, yang menjelaskan tentang sertifikat kompetensi sebagai tanda pengakuan terhadap kemampuan seorang dokter atau dokter gigi untuk menjalankan praktik kedokteran seluruh Indonesia setelah lulus uji kompetensi yang dikeluarkan oleh kolegium terkait ( Abdillah,2016; Konsil Kedokteran Indonesia, 2015).

Materi uji kompetensi merujuk pada Standar Kompetensi Dokter Indonesia yang ditetapkan oleh Konsil Kedokteran Indonesia. Uji kompetensi dilaksanakan dengan menggunakan metode yang tepat dalam menguji sikap (attitude), pengetahuan (knowledge) dan keahlian (skills). Materi uji kompetensi disusun berdasarkan cetak biru (blueprint).Masing-masing metode, baik untuk metode uji CBT maupun uji OSCE memiliki blueprint yang selanjutnya menjadi dasar dalam 
pelaksanaan uji kompetensi dokter (Sugiharto, 2013).

Menurut Undang- undang, UKMPDD berlaku bagi setiap calon lulusan pendidikan profesi dokter dengan beberapa persyaratan seseuai Konsil Kedokteran Indonesia (Indah, 2017). Bandura menjelaskan bahwa Self efficacy merupakan keyakinan individu tentang kemampuan dirinya untuk mengorganisasikan dan melaksanakan tugas dan tindakan yang diinginkan agar mencapai hasil yang maksimal (Engko, 2008: Mukhid, 2009). Self efficacy adalah penilaian seseorang tentang kemampuannya sendiri untuk menjalankan perilaku tertentu atau mencapai tujuan tertentu. Self efficacy merupakan suatu keyakinan (belief) yang terbentuk dari suatu proses kognitif yang dilakukan seseorang dalam suatu situasi (Jatisunda, 2017).Latipah (2010) mengatakan bahwa Self efficacy seseorang dibedakan atas tiga dimensi yang memiliki implikasi penting terhadap performansi, begitu juga dengan performansi akademik siswa. Dimensi-dimensi tersebut antara lain:

a) Perbedaan level (tingkat kesulitan tugas). Level merupakan tingkat kesederhanaan atau kerumitan tugas yang diyakini dapat diselesaikan.

b) Luas bidang perilaku (generality). Generality menggambarkan rentang (range) tugas yang dirasa dapat diselesaikan. Beberapa individu akan merasa mampu menyelesaikan tugas dengan range yang luas.

c) Keyakinan (strength). Strength merupakan kepercayaan diri seseorang yang dapat diwujudkan dalam meraih prestasi tertentu. Nilai strength yang tinggi lebih menggambarkan keteguhan hatinya dalam menghadapi berbagai rintangan untuk menyelesaikan tugas yang diberikan. Dimensi kemantaban akan keyakian yang terbagi dua sub, yaitu: pertama, bertahan dalam usaha; kedua, keuletan dalam usaha (upaya).

Self efficacy dapat mempengaruhi performansi, ketekunan, menentukan pilihan, dan tindakan mendekati atau menyelesaikan tugas. Individu yang memiliki self efficacy yang tinggi akan mengarahkan seseorang pada prestasi yang lebih baik dalam berbagai bidang karena efikasi diri itu akan mengaktifkan perubahan psikologi yang mengurangi rasa sakit dan lebih dapat mentolerir stress (Astarini, 2015; Wibowo, 2010).

\section{METODE PENELITIAN}

Self Efficacy adalah seberapa besar keyakinan individu tentang kemampuan dirinya untuk menyelesaikan tekanan-tekanan yang membuat stres yang diukur dengan menggunakan skala efikasi diri yang didasarkan atas 3 dimensi efikasi diri, yaitu: Perbedaan level (tingkat kesulitan tugas), Luas bidang perilaku (generality) dan Keyakinan (strength) (Hartawati \& Mayani, 2014; Handayani, 2013; Widanarti \& Indati, 2002). Kelulusan peserta retaker UKMPPD dilihat berdasarkan skor yang diperoleh saat mengikuti ujian UKMPPD. Peserta dinyatakan lulus ujian UKMPPD, jika mendapatkan skor > 66 (Santoso, Lusida, Farida \& Husaeni, 2017). Rancangan penelitian ini bersifat analitik observasional dengan pendekatan cross sectional untuk mengukur self efficacy pada mahasiswa profesi dokter.

Subjek pada penelitian ini adalah mahasiswa Program Profesi Dokter yang mengikuti ujian UKMPPD di Universitas Malahayati.Mahasiswa tersebut diminta untuk menandatangani lembar persetujuan (Informed Consent). Sampel diambil dengan menggunakan teknik purposive sampling. Karakteristik sampel dalam penelitian ini adalah mahasiswa profesi dokter yang menjadi retaker pertama pada ujian UKMPPD (Suryabrata, 1998). Dokumen Kelulusan Retaker UKMPPD diperoleh dari nilai hasil ujian UKMPPD di Universitas Malahayati.

Skala yang digunakan dalam penelitian ini adalah skala Self Efficacy (Bandura, 1997) yang didasarkan atas tiga dimensi efikasi diri, yaitu: Perbedaan level (tingkat kesulitan tugas), Luas bidang perilaku (generality) dan Keyakinan (strength). Skala yang akan mengungkap butirbutir dalam skala model Likert yang disusun dengan memperhatikan sifat favourable dan unfavourable (Azwar, 1999). Kemudian untuk uji Validitas dan reliabilitas dilakukan pada alat ukur self efficacy. 
HUBUNGAN ANTARA SELF EFFICACY (KEYAKINAN KEMAMPUAN DIRI) DENGAN KELULUSAN RETAKER UKMPPD DI UNIVERSITAS MALAHAYATI

Tabel 1. Bule Print Self Efficacy

\begin{tabular}{lccc}
\hline & \multicolumn{2}{c}{ Self Efficacy } & Total \\
\cline { 2 - 3 } \multicolumn{1}{c}{ Aspek-Aspek } & Fav & Unfav & 10 \\
\hline $\begin{array}{l}\text { Perbedaan level } \\
\text { (tingkat kesulitan }\end{array}$ & $1,7,13,19,25$ & $4,10,16,22,28$ & \\
$\begin{array}{l}\text { tugas) } \\
\text { Luas bidang }\end{array}$ & $2,8,14,20,26$ & $5,11,17,23$ & 9 \\
$\begin{array}{l}\text { perilaku } \\
\text { (generality) }\end{array}$ & $3,9,15,21,27$ & $6,12,18,24,29,30$ & 11 \\
$\begin{array}{l}\text { Keyakinan } \\
\text { (strength). } \\
\text { Jumlah }\end{array}$ & $\mathbf{1 5}$ & $\mathbf{1 5}$ & $\mathbf{3 0}$ \\
\hline
\end{tabular}

Metode analisis data yang digunakan adalah analisis statistik. Teknik yang digunakan adalah teknik korelasi product moment untuk mengukur self efficacy pada re-taker UKMPPD dengan menggunakan bantuan program SPSS 20 for windows. Untuk menguji reliabilitas alat ukur menggunakan teknik Alpha Cronbach. Koefisien reliabilitas skala yang kurang dari 0,6 dinilai kurang baik. Koefisien reliabilitas 0,7 dapat diterima, sedangkan diatas 0,8 adalah baik (Hamdi, 2015).

\section{HASIL}

Peneliti menggunakan model try out berdasarkan hasil data yang diperoleh digunakan untuk mencari validitas dan relibilitas kemudian item-item yang valid disusun kembali untuk pengambilan data sebenarnya.

Setelah dilakukan uji validitas dan diperoleh item-item yang valid kemudian skala self efficacy diperbaiki dengan membuang nomor-nomor item yang gugur untuk kemudian skala tersebut diberikan kembali kepada subjek penelitian untuk data penelitian.

Berdasarkan hasil uji validitas terhadap alat ukur Self Efficacy terdapat 25 item yang valid yang memiliki skor corected item total corelation yang begerak dari 0,320 - 0,719. Berdasarkan hasil uji reliabilitas dengan menggunakan rumus alpha cronbach diperoleh skor sebesar 0,873 . Hal ini dapat dikatakan bahwa skala tersebut dinyatakan reliable. 
HUBUNGAN ANTARA SELF EFFICACY (KEYAKINAN KEMAMPUAN DIRI) DENGAN KELULUSAN RETAKER UKMPPD DI UNIVERSITAS MALAHAYATI

Tabel 2. Karakteristik Subjek Penelitian ( $\mathrm{N}=106)$

\begin{tabular}{lcc}
\hline & Berdasarkan Jenis Kelamin \\
\hline Laki-laki & Frekuensi & Prosentase \\
Perempuan & 38 & $35,8 \%$ \\
Total & 68 & $64,2 \%$ \\
& 106 & $100 \%$ \\
Retaker 1 & Berdasarkan Status Retaker & \\
Retaker 2 & 20 & $18,9 \%$ \\
Retaker 3 & 20 & $18,9 \%$ \\
Retaker 4 & 19 & $17,9 \%$ \\
Retaker $>4$ & 19 & $17,9 \%$ \\
Total & 28 & $26,4 \%$ \\
& 106 & $100 \%$ \\
Lulus & Berdasarkan Kelulusan & \\
Tidak Lulus & 41 & $38,7 \%$ \\
Total & 65 & $61,3 \%$ \\
\hline
\end{tabular}

Tabel 3. Hasil Uji Validitas Self Efficacy

\begin{tabular}{lcccc}
\hline \multicolumn{1}{c}{ Aspek-Aspek } & Item Semula & $\begin{array}{c}\text { Item } \\
\text { Gugur }\end{array}$ & Item Valid & $\begin{array}{c}\text { Corrected Item- } \\
\text { Total Correlation }\end{array}$ \\
\hline Perbedaan level (tingkat kesulitan tugas) & 10 & 3 & 7 & $0,320-0,679$ \\
Luas bidang perilaku (generality) & 9 & 1 & 8 & $0,338-0,550$ \\
Keyakinan (strength). & 11 & 1 & 10 & $0,338-0.719$ \\
Jumlah & $\mathbf{3 0}$ & $\mathbf{6}$ & $\mathbf{2 5}$ & $\mathbf{0 , 3 2 0 - 0 , 7 1 9}$ \\
\hline
\end{tabular}

Sumber: Data Primer Tahun 2018, (diolah SPSS Versi 20.0)

Tabel 4. Analisis Deskriptif

\begin{tabular}{lccccccccc}
\hline & \multicolumn{4}{c}{ Skor Empirik } & \multicolumn{4}{c}{ Skor Hipotetik } \\
\cline { 2 - 9 } & $\sum^{\text {Item }}$ & Min & Max & Mean & Sd & Min & Max & $\boldsymbol{\mu}$ & $\boldsymbol{\Sigma}$ \\
\hline Self & 30 & 25.00 & 86.00 & 49.46 & 16.79 & 25 & 100 & 12,5 & 50 \\
Efficacy & & & & & & & & & \\
\hline
\end{tabular}


HUBUNGAN ANTARA SELF EFFICACY (KEYAKINAN KEMAMPUAN DIRI) DENGAN KELULUSAN RETAKER UKMPPD DI UNIVERSITAS MALAHAYATI

Tabel 5. Data Deskriptif Self Efficacy

\begin{tabular}{cccc}
\hline Interval & Kategori & Frekuensi & $\%$ \\
\hline$\geq 62,5$ & Tinggi & 22 & $20,75 \%$ \\
$37,5-62,5$ & Sedang & 47 & $44,34 \%$ \\
$\leq 37,5$ & Rendah & 37 & $34,91 \%$ \\
\hline
\end{tabular}

Berdasarkan hasil analisis deskripsi yang menggunakan aplikasi SPSS diketahui bahwa distribusi skor self efficacy tersebar antara 25 sampai 86. Berdasarkan analisis deskriptif di atas maka apabila sebaran skor pada tiap skala dikelompokkan ke dalam interval nilai yang masing-masing interval mewakili kategori tertentu, maka diperoleh hasil seperti pada tabel 4 .

Berdasarkan kategorisasai skor self efficacy diatas terlihat bahwa mayoritas jawaban seluruh subyek dari skala self efficacy berada pada ketegori sedang yaitu dengan frekuensi 47 dan presentase $44,34 \%$ pada keseluruhan subyek, kategori tinggi dengan frekuensi 22dan presentase $20,75 \%$ sedangkan pada kategori rendah berjumlah 37 dan persentase $34,91 \%$.

Uji normalitas sebaran dilakukan untuk mengetahui apakah populasi data berdistribusi normal atau tidak, data dinyatakan berdistribusi normal apabila signifikasi lebih besar dari 0.05 . Uji normalitas dilakukan menggunakan uji OneSample Kolmogorof-Smirnov Test dalam aplikasi SPSS. Normalitas masing-masing skala dapat dilihat dari besarnya koefisien Kolmogorof-Smirnov Z (Sumarjo, 2010).

Hasil uji hipotesis dengan teknik Analisis Product Momen dari Pearson dengan menggunakan softwareStastitical Product and Service Solution (SPSS) versi 20.0, hasil (output) ada hubungan positif yang sangat signifikan antara self efficacy dengan kelulusan retaker UKMPPD Universitas Malahayati Bandar Lampung. Artinya hipotesis yang diajukan dalam penelitian ini terbukti.Berdasarkan hasil analisis selanjutnya, diketahui variabel self efficacy memberikan sumbangan efektif sebesar $67 \%$. artinya masih terdapat variabel lain yang mempengaruhi tingkat kelulusan retaker peserta UKMPPD.

Hasil ini menunjukkan ada hubungan antara self efficacy (keyakinan kemampuan diri) dengan kelulusan etaker UKMPPD Di Universitas Malahayati artinya semakin tinggi self efficacy maka semakin tinggi kelulusan, sebaliknya semakin rendah self efficacy yang dimiliki oleh individu maka semakin kecil kelulusan peserta retaker UKMPPD. Berdasarkan kategorisasi pada skala self efficacy mayoritas tingkat self efficacy mahasiswa peserta retaker UKMPPD berada pada kategori sedang dengan jumlah frekuensi 47 , kategorisasi tinggi sebanyak 22 subjek dan kategorisasi rendah jumlah frekuensi 37 subjek. Berdasarkan data tersebut menunjukkan bahwa masih banyak subjek penelitian yang memilikiself efficacy yang rendah, yang sangat berpengaruh pada tingkat kelulusan pada peserta retaker UKMPPD Universitas Malahayati.

Self efficacy dapat mempengaruhi performansi, ketekunan, menentukan pilihan, dan tindakan mendekati atau menyelesaikan tugas. Individu yang memiliki self efficacy yang tinggi akan mengarahkan seseorang pada prestasi yang lebih baik dalam berbagai bidang karena efikasi diri itu akan mengaktifkan perubahan psikologi yang mengurangi rasa sakit dan lebih dapat mentolerir stress (Astarini, 2011; Ardianty \& Alsa 2015; Nurlaila, 2011). Berdasarkan hasil penelitian ini dapat menjadi dasar untuk membuat treatment bagi peserta UKMPPD khususnya yang retaker dengan memberikan pelatihan meningkatkan self efficacy sebagai salah satu upaya untuk meningkatkan jumlah kelulusan peserta UKMPPD Universitas Malahayati.

\section{SIMPULAN}

Berdasarkan hasil penelitian dan pembahasan, maka dapat diambil beberapa simpulan, sebagai berikut : Terdapat hubungan antara self efficacy dengan kelulusan retaker UKMPPD Universitas Malahayati Bandar Lampung dengan nilai $r=0,673$ dengan $P=0,000$ dimana $(p<0,01)$. Semakin tinggi self efficacy yang dimiliki oleh peserta retaker UKMPPD maka semakin besar tingkat kelulusannya, sebaliknya semakin rendah self efficacy yang dimiliki oleh peserta retaker UKMPPD maka semakin rendah tingkat kelulusannya. Variabel self efficacy memiliki 
sumbangan terhadap tingkat kelulusan sebesar $67,3 \%$, artinya masih terdapat faktor lain yang mempengaruhi tingkat kelulusan retaker UKMPPD sebesar $33,7 \%$ misalnya inteligensi dan kecemasan.

Berdasarkan kategorisasi tingkat self efficacy pada peserta retaker UKMPPD kategori sedang dengan jumlah frekuensi 47, kategorisasi tinggi sebanyak 22 subjek dan kategorisasi rendah jumlah frekuensi 37 subjek. Berdasarkan data tersebut dapat menjadi salah satu dasar untuk dapat dilakukan treatment pada peserta retaker UKMPPD dengan memberikan pelatihan self efficacy sebagai upaya untuk meningkatkan keyakinan akan kemampuan dirinya dalam menghadapi UKMPPD di Universitas Malahayati Bandar Lampung

\section{DAFTAR PUSTAKA}

Abdillah, A. (2016). Analisis faktor-faktor yang mempengaruhi kelulusan uji kompetensi ners Indonesia. JPAP: Jurnal Penelitian Administrasi Publik, 2(02).

Ardiyanti, D., \& Alsa, A. (2015). Pelatihan "PLANS" untuk Meningkatkan Efikasi Diri dalam Pengambilan Keputusan Karir. Gadjah Mada Journal of Professional Psychology (GamaJPP), 1(1).

Astarini, I. (2015). Pengaruh self efficacy, prestise profesi guru dan status sosial ekonomi orang tua terhadapminat menjadi guru akuntansi pada mahasiswa pendidikan akuntansi 2011 FE UNNES (Doctoral Dissertation, Universitas Negeri Semarang).

Azwar, S. (1999). Penyusunan skala psikologi. Pustaka pelajar.

Dwitantyanov, A., Hidayati, F., \& Sawitri, D. R. (2010). Pengaruh pelatihan berpikir positif pada efikasi diri akademik mahasiswa (studi eksperimen pada mahasiswa fakultas psikologi undip semarang. Jurnal Psikologi, 8(2), 135144.
Engko, C. (2008). Pengaruh kepuasan kerja terhadap kinerja individual dengan self esteem dan self efficacy sebagai variabel intervening. Jurnal bisnis dan akuntansi, 10(1), 1-12.

Hamdi, A. S., \& Bahruddin, E. (2015). Metode penelitian kuantitatif aplikasi dalam pendidikan. Deepublish.

Handayani, F. (2013). Hubungan self efficacy dengan prestasi belajar siswa akselerasi. Character: Jurnal Penelitian Psikologi., 1(2).

Hartawati, D., \& Mariyanti, S. (2014). Hubungan antara Self-efficacy dengan Burnout pada Pengajar Taman Kanak-kanak Sekolah "X" di Jakarta. Jurnal Psikologi Esa Unggul, 12(02).

Indah, S. N. (2017). Hubungan pembimbingan terhadap kelulusan ujian CBT UKMPPD nasional mahasiswa fakultas kedokteran Universitas Lampung Periode Agustus 2015Mei 2016.

Jatisunda, M. G. (2017). Hubungan self-efficacy siswa SMP dengan kemampuan pemecahan masalah matematis. Theorems (The Original Research of Mathematics), 1(2).

Kementerian Riset, Teknologi, dan Pendidikan Tinggi Republik Indonesia. (2015). Laporan Akuntabilitas Kinerja Kementerian Riset, Teknologi, dan Pendidikan Tinggi Republik Indonesia Tahun 2015

Konsil Kedokteran Indonesia. (2006). Standar pendidikan profesi dokter. Jakarta: Konsil Kedokteran Indonesia.

Kusumadewi, R. R. (2014). Hubungan Efikasi Diri, Kemandirian Belajar Dan Motivasi Berprestasi Dengan Prestasi Belajar Mahasiswa (Doctoral dissertation, UNS (Sebelas Maret University)).

Latipah, E. (2010). Strategi self regulated learning dan prestasi belajar: kajian meta analisis. Jurnal Psikologi, 37(1), 110-129. 
HUBUNGAN ANTARA SELF EFFICACY (KEYAKINAN KEMAMPUAN DIRI) DENGAN KELULUSAN RETAKER UKMPPD DI UNIVERSITAS MALAHAYATI

Mukhid, A. (2009). Self-Efficacy (Perspektif Teori Kognitif Sosial dan Implikasinya terhadap Pendidikan). Tadris: Jurnal Pendidikan Islam, 4(1)

Nurlaila, S. (2011). Pelatihan efikasi diri untuk menurunkan kecemasan pada siswa-siswi yang akan menghadapi ujian akhir nasional. Guidena: Jurnal IImu Pendidikan, Psikologi, Bimbingan dan Konseling, 1(1), 1-22.

Pudjiastuti, E. (2012). Hubungan "self efficacy" dengan perilaku mencontek mahasiswa psikologi. Mimbar, Jurnal Sosial dan Pembangunan, 28(1), 103-111.

Sahertian, P. (2011). Perilaku Kepemimpinan Berorientasi Hubungan Dan Tugas Sebagai Anteseden Komitmen Organisasional, SelfEfficacy Dan Organizational Citizenship Behavior (OCB). Jurnal Manajemen Dan Kewirausahaan, 12(2), 156-169.

Santoso, S. S., Lusida, N., Farida, I., \& Husaeni, A. F. (2017). Analisis Efektivitas Pembimbingan Mahasiswa Dalam Persiapan Mengikuti UKMPPD (Uji Kompetensi Mahasiswa Pendidikan Profesi Dokter) Terhadap Kelulusan UKMPPD Nasional Periode 2016. Proceeding APKKM 2017.

Sugiharto, L. (2013). Alternatif Penyusunan Kurikulum Mengacu pada KKNI. Jakarta: Tim Sosialisasi Kurikulum Dikti.

Sumarjo, H. (2010). Pengaruh karakteristik pemerintah daerah terhadap kinerja keuangan pemerintah daerah (Doctoral dissertation, UNS).
Suryabrata, S. (1998). Metode penelitian. Jakarta: PT Raja Grafindo Persada

Sutomo, N., Hartono, A., \& Dwipayanti, P. I. (2017). Pemberdayaan Masyarakat Dalam Pelaksanaan PSN Melalui Gerakan Jumantik Cilik. Jurnal Keperawatan dan Kebidanan, 9(1).

Warsito, H. (2012). Hubungan antara self-efficacy dengan penyesuaian akademik dan prestasi akademik (Studi pada mahasiswa FIP Universitas Negeri Surabaya). Pedagogi: Jurnal IImu Pendidikan, 9(1), 29-47

Wibowo, N. R. (2010). Hubungan Antara Locus Of Control Internal Dan Self Efficacy Dengan Kepuasan Kerja Karyawan Departemen Spinning PT. Daya Manunggal (Doctoral dissertation, Universitas Sebelas Maret).

Widanarti, N., \& Indati, A. (2002). Hubungan antara dukungan sosial keluarga dengan self efficacy pada remaja di SMU Negeri 9 Yogyakarta. Jurnal psikologi, 29(2), 112-123.

Widyastuti, R. J, \& Pratiwi, T. I. (2013). Pengaruh self efficacy dan dukungan sosial keluarga terhadap kemantapan pengambilan keputusan karir siswa. Jurnal BK UNESA, 3(1).

Wijaya, T. (2008). Hubungan adversity intelligence dengan intensi berwirausaha (studi empiris pada siswa SMKN 7 Yogyakarta). Jurnal Manajemen dan Kewirausahaan, 9(2), 117-127. 